2016-04-11

\title{
Peer abuse and its contexts in industrial schools in Ireland
}

\author{
Lynch, JJ
}

http://hdl.handle.net/10026.1/15678

10.1108/jacpr-11-2015-0199

Journal of Aggression, Conflict and Peace Research

Emerald

All content in PEARL is protected by copyright law. Author manuscripts are made available in accordance with publisher policies. Please cite only the published version using the details provided on the item record or document. In the absence of an open licence (e.g. Creative Commons), permissions for further reuse of content should be sought from the publisher or author. 


\section{Emerald Insight}

\section{Journal of Aggression, Conflict and Peace Research}

Peer abuse and its contexts in industrial schools in Ireland Jeremiah J. Lynch Stephen James Minton

\section{Article information:}

To cite this document:

Jeremiah J. Lynch Stephen James Minton , (2016),"Peer abuse and its contexts in industrial schools in Ireland", Journal of Aggression, Conflict and Peace Research, Vol. 8 Iss 2 pp. -

Permanent link to this document:

http://dx.doi.org/10.1108/JACPR-11-2015-0199

Downloaded on: 09 March 2016, At: 11:48 (PT)

References: this document contains references to 0 other documents.

To copy this document: permissions@emeraldinsight.com

The fulltext of this document has been downloaded 1 times since 2016*

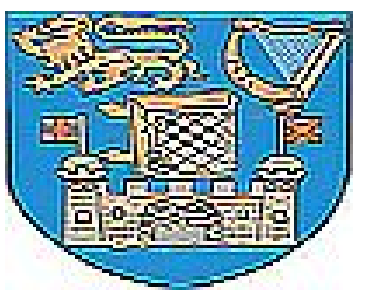

Access to this document was granted through an Emerald subscription provided by emerald-srm: 327720 []

\section{For Authors}

If you would like to write for this, or any other Emerald publication, then please use our Emerald for Authors service information about how to choose which publication to write for and submission guidelines are available for all. Please visit www. emeraldinsight. com/authors for more information.

\section{About Emerald www.emeraldinsight.com}

Emerald is a global publisher linking research and practice to the benefit of society. The company manages a portfolio of more than 290 journals and over 2,350 books and book series volumes, as well as providing an extensive range of online products and additional customer resources and services.

Emerald is both COUNTER 4 and TRANSFER compliant. The organization is a partner of the Committee on Publication Ethics (COPE) and also works with Portico and the LOCKSS initiative for digital archive preservation.

*Related content and download information correct at time of download. 


\section{Peer abuse and its contexts in industrial schools in Ireland}

\section{Introduction}

The industrial school system in Ireland, which was to last over a century, involved the institutionalisation of generations of children in bleak, inhospitable reformatory schools, run entirely autocratically by the religious orders, and socially (and more often than not, geographically) marginalised from the rest of Irish society (Maguire, 2012). With the hand-in-glove relationship that existed (and some would argue, still exists) between Church and State in Ireland, the publication of survivors' accounts of these institutions (Clemenger, 2009; Finn, 2012; Flynn 1983; Touher, 2001; Tyrrell, 2006; Wall, 2013), and official investigations into what took place (Commission to Inquire into Child Abuse [hereafter, referred to as CICA], 2009), have been a feature of only the last twenty years. However, what has emerged is a picture of horrific incidences and frequencies of physical and sexual abuse, which was apparently commonplace in these institutions (CICA, 2009). The abuse was perpetrated on the child and adolescent pupils by adults; it also - and hence the submission of this paper to this special edition of this journal - took place between the children and adolescents themselves (CICA, 2009; Clemenger, 2009; Touher, 2001, 2008; Wall, 2013).

Our overall purpose for this paper is to make the peer abuse that took place in industrial schools in Ireland comprehensible. In attempting to do so, the major sections of this paper will serve the following aims:

(i) to provide a history of how the industrial schools system in Ireland developed;

(ii) to provide a description of the patterns of both institutional, and peer abuse, which have been accrued from an examination of official reports into, and survivor accounts written by the detainees of, the six industrial schools run by the Christian Brothers in Ireland; and,

(iii) to consider such peer abuse within the contextual frames of primary adjustment, collaboration and repetition compulsion.

\section{The Development of the Industrial Schools System in Ireland}

Historically, the system of industrial schools in Ireland owes much to the workhouse model established during the 1840s as a response to the poverty caused by the Irish Famine. It can be traced back to the work of pioneering penal reformer, anti-slavery activist and educationalist, Mary Carpenter, who had been moved by the plight of destitute children and juvenile offenders she had seen in the Bristol of the 1840s. Carpenter rejected the then-common practice of committing children to prison for offences, arguing that magistrates and judges should instead send convicted 
children to reform schools (Carpenter, 1851 / 2013). Carpenter founded her first 'ragged school' in 1846, and her first reformatory in 1852, based firmly on principles of rehabilitation rather than retribution. The establishment of these schools led ultimately to the passing of the Youthful Offenders Act (1854) and the Industrial Schools Act (1857), formally establishing the network of residential institutions in England. Ireland's Industrial Schools Act (1868), which was based entirely on the British Act of 1857, established residential institutions in Ireland to care for neglected, orphaned and abandoned children from age 6 to 16 years (Arnold \& Laskey, 1985). The main objective of the system was to inculcate in children the habits of '....industry, regularity, self-denial, self-reliance and selfcontrol' (O’Sullivan \& O’Donnell, 2007).

Institutionalisation had been seen as a legitimate and effective response to the large numbers of vagrant children left without parents during and after the Irish Famine. These children were drawn to the cities where, in order to survive, they engaged in begging and stealing - in 1852, one-twelfth of annual committals were of juveniles under the age of 16 (Barnes, 1989). Public concern at juvenile criminality became so pronounced that any official concerned party could request a committal order. Hence, the National Society for the Prevention of Cruelty to Children (NSPCC), and subsequently (following Ireland's independence), the Irish Society for the Prevention of Cruelty to Children (ISPCC) sought committal for cases involving lack of proper guardianship. This category included neglect of the child, very often as a direct result of poverty; this was especially the case in Dublin, where the slums were described as being the worst in Europe (Buckley, 2013). School attendance officers, too, sought committal for non-attendance. Maguire (2012) notes that judges were only too willing to grant committal orders, with little investigation into family circumstances and background and few efforts to help needy families in ways that did not involve sending children to industrial schools. Hence, the Gardaí (An Garda Síochána, the national police force of the Republic of Ireland), the school attendance officer and the NSPCC / ISPCC representative (known colloquially as the 'cruelty man') were feared by many children, and were often used as a threats against them by parents, teachers and other figures of authority.

For many Irish children, the threat was not an idle one. In the century from 1868 to 1969 , over 105,000 children were detained in Irish industrial schools, having been committed by the courts. Section 58(1) of the Children Act, 1908 (as amended by the Children Acts, 1929 and 1941), allowed for the detention of a child or young person under three broad categories: 'lack of proper guardianship', 'non-attendance at school', and 'indictable offences' (Raftery \& O'Sullivan, 1999, p.20). By 1966, a fourth category of 'uncontrollable' had been added (Tuairim, 1966). Children who had 
committed indictable offences were brought before the courts by the Gardaí just like adults - prior to the Children Act (2001), where the age of criminal responsibility in Ireland was effectively raised to 12 years, it was 7 years. Offences could be at the mild end of the scale; and, whilst a parent was required by law to be present at the hearing, the children were almost always [legally] unrepresented, and were usually not questioned or consulted in any way before the order for detention was made (CICA, 2009). A further 16,000 children (the vast majority of whom were boys) were committed to reformatories during the same period of time (Raftery \& O'Sullivan, 1999). With the inclusion of children detained in other residential institutions such as county homes, the overall total of children so committed amounted to around 170,000 , and hence involved about $1.2 \%$ of the age cohort (CICA, 2009).

The institutions themselves were operated, in the main, by Roman Catholic religious orders, the largest providers being the Congregation of Christian Brothers and the Sisters of Mercy. The development of the industrial school system was, therefore, inextricably tied in with the vision of the predominant church, whose efforts were aimed at '....increasing its influence and control over the hearts and minds of its "flock" and the [religious] orders were its foot soldiers' (Chapman \& O’Donoghue, 2007, p. 563). Lynch \& Burns (2012) concluded that the Irish state simply handed these children over to the Catholic Church, without any effective system of accountability or safeguards. With such a proportion of the nation's children being detained, the archipelago of industrial schools became extensive, with 71 schools being scattered throughout the country and holding approximately 8,000 children at its peak operating capacity in 1898 (Kennedy Report, 1970). The creation and rapid proliferation of the schools can be seen as either '..... desire to help the needy, or a need to control those whom the authorities viewed as a threat to the existing order' (CICA, 2009, Vol.1, p.36).

Barnes (1989, p.88) states that children were committed to the schools to ensure that they became decent, law-abiding citizens, and that legislators were concerned with protecting society from crime, and rescuing children from a life of sin and moral degradation. If not reformed, such children would grow up to become members of the dangerous classes, ready to prey on polite society. Miller (in MacLellan \& Mauger, 2013, p.107) argued that by the mid-nineteenth century, the industrial schools and reformatories in Ireland served as the key sites of bodily, psychological and moral reform for potential adult criminals. He referred to them as 'moral hospitals', noting that at the time child criminality was believed to have organic causes, and that industrial schools and reformatories constituted the systematic effort to reform children physically, mentally and morally. All of this 
reforming took place in an atmosphere controlled by strict codes of military-style order reinforced by severe punishments (Coldrey, 2001). Detainees were meant to internalise the values of the Christian Brothers, accept their status as morally corrupt, agree with the methods used to rehabilitate them and generally be quiet, compliant, respectful and well-behaved, in accordance with middle-class management expectations (Coldrey, 2001). Barnes (1989, p. 88) concluded that the whole process amounted to an exercise in social genetics. Fergusen (2007) believed that children in residential institutional detention were so stigmatised that they were seen as the moral dirt of Irish society, and that preying on the fears of the general public was how the residential institution concept was sold to them.

\section{Institutional Abuse and Industrial Schools}

How people cope with, and adapt to, a period of incarceration has been studied for over seventy years (Clemmer, 1940; Garabedian, 1964; Sykes, 1958; Sykes \& Messinger, 1960). Physical violence is part of the prison experience because prisoners are detained against their wills, they are forced to do things they would not normally do, they are confined with people they may not like, and some of them are inclined to be violent (Stohr \& Walsh, 2015), and an institutional sub-culture also promotes violence as a means of resolving conflicts; hence, threats, verbal abuse and physical assault have been found to be pervasive elements of prison life in UK prisons (Edgar \& Newell, 2003). Furthermore, violent incidents in prisons tend to be under-reported for a number of reasons including the threat of retaliation, being labelled an informer, the belief that nothing will be done about the complaint, and the embarrassment at being perceived as a victim (Ricciardelli, 2014). According to the National Inmate Survey for $2011 / 2012$, four per cent of American prison inmates reported experiencing sexual assault, perpetrated by either other inmates or staff; younger inmates (under age 34), those with a college degree, those who were LGBTI, and those suffering from a mental illness were more likely to be sexually assaulted (Beck et al, 2013). In the United Kingdom, the Howard League for Penal Reform (2014) noted that whilst there has been minimal research on sexual assault in prisons, prison sexual crime is under-reported. Banbury (2004), for example, found that one per cent of a sample of ex-prisoners who had been incarcerated in British prisons reported that they had been raped, and that 5.3 per cent reported that they had been the victims of coerced sex. Gay and transgender prisoners were found to be at a greater risk of sexual assault than heterosexual prisoners.

The common factors of industrial schools in Ireland have been described by Arnold (2009, pp. 3-7) as being (i) penal, in that '.....all who went through the system recall, above all else, the punitive nature of their treatment and universal lack of kindness 
and affection in the way they were treated'; children were put through a sequence of experiences that '....categorised them as prisoners': they were arrested or taken into charge, appeared before a judge in a court setting and were sentenced to a period of detention; (ii) (2) secret, in that the institutions '....masqueraded as something else (schools) and the subterfuge of Church and State....was widely accepted by the Irish people'; and, (iii) punitive, in that the system had punishment regimes in place, and that these were '....chronically excessive, cruel and perverse'. In these very real senses, industrial schools in Ireland were prisons for children and adolescents.

In the Irish school system as a whole, the corporal punishment of children was legal up to 1982, and its use did not constitute a criminal offence until 1996. Rules were alarmingly lacking in detail when it came to the limits of corporal punishment in industrial schools (Arnold \& Laskey, 1985). The Rules and Regulations for the Certified Industrial Schools issued by the Irish government's Department of Education instructed that punishments were to consist of: (i) 'forfeiture of rewards and privileges, or degradation from rank, previously attained by good conduct'; (ii) 'moderate childish punishment with the hand'; and, (iii) 'chastisement with the cane, strap or birch' (Cussen 1936, Appendix C, p.63). Officially, punishment in an industrial school was to be carried out only by the Resident Manager or someone nominated by him. No punishments, other than those mentioned above, were to be administered. The Congregation of Christian Brothers was the largest provider of places in Irish industrial schools for boys, operating six such schools, scattered throughout the country, and certified to take a total of 1,750 boys. The CICA investigated all six schools, and in every one, there were allegations of abuse and neglect that the Commission found to be credible; what appears in the Commission's report reads as a catalogue of abuse and neglect perpetrated on vulnerable children. All industrial schools were to keep a punishment book in which the offences and the relevant punishments were to be entered, and these books were to be made available to Department of Education inspectors. Although there were 52 industrial schools operating in the $20^{\text {th }}$ century, only two of these books were ever made available to the CICA. In a study of 247 adult survivors of the various residential institutions for children and adolescents, almost all reported having experienced physical neglect (97.6 per cent), physical abuse (97.2 per cent), and emotional neglect (95.1 per cent) as children in these schools; furthermore, almost half (47 per cent) reported having been sexually abused (CICA, 2009).

\section{Peer Abuse, Primary Adjustment and the Issue of 'Collaboration'}

Goffman (1961) argued that most of the time detainees in total institutions are induced to co-operate, by threats of punishment and penalty if they do not, and that this type of authoritarian, physically violent regime is designed to break the 
individual's spirit, and usually results in submission. Goffman referred to this method of adaption as 'primary adjustment'. He noted that it is normal in total institutions for detainees to obey the rules through fear, or some other mechanisms. O'Sullivan $(1976,1978)$ found this mode of adaptation to be in evidence in one industrial school (St. Joseph's, Letterfrack, Co. Galway), when he administered an Adaptation Checklist to 40 detainees. He found a strong level of detainee support for conformity to school demands, as evidenced by their majority endorsement of the following statements: 'pupils here should be friendly with the Brothers' (33/40); 'boys here should do their best to keep the school rules' (28/40); 'boys here should do what they're told by the Brothers' (30/40); 'you should make the best of things while you're here and keep out of trouble' (33/40). In addition, he found that the longer a boy was detained in the industrial school the more likely he was to endorse items indicating conformity (O' Sullivan, 1976, 1978). As Goffman (1961) might have expected, because of this seemingly internalised support for compliance with the wishes of the Christian Brothers and conformity to the norms in the institution, the issue of co-operation, or 'collaboration' with the authorities, was inevitably raised in the minds of the detainees, and in the behaviour of some.

The collaboration with the authorities that was an on-going issue in the six Christian Brothers-operated industrial schools In Ireland (these were located in Letterfrack, Co. Galway; Salthill, Co. Galway; Glin, Co. Limerick; Artane, Dublin; Carriglea, Dún Laoghaire, Co. Dublin; and Tralee, Co. Kerry) may have partly resulted from the introduction of a special category of older supervising boy (known as a 'monitor') in those schools. It seems the idea behind having these monitors was for them to provide supervisory assistance to the teaching Brothers. This would make it easier to deal with large numbers of detainees and would encourage detainee cooperation. Monitors also distributed food in the dining hall and supervised the boys in the yard at playtime and in the dormitories in the evenings, among other duties. They received privileges for their co-operation. In most industrial schools the other detainees despised them, viewing them as spies and collaborators. It appears that monitors were authorised to punish those detainees in their charge and there is some evidence that, emboldened by this power, some physically and sexually abused the boys they were in charge of (CICA, 2009).

Wall (2013) revealed that monitors in the Gin industrial school in received extra bread at mealtime. The CICA Report (2009) notes that monitors in the industrial school in Tralee wrote down the offences committed by fellow detainees and reported directly to a Brother, who then punished those boys (CICA Report, 2009). Monitors in the Carriglea industrial school were chosen from among the senior detainees, and helped with supervision in the dining hall, playground and 
dormitories (CICA Report, 2009). Monitors in the Artane industrial school were each put in charge of a cohort of over fifty detainees, and were also called 'squealers'. They distributed letters and parcels from home (Touher, 2001). Tyrrell (2006, p.33) describes a particularly abusive monitor in the Letterfrack industrial school:

'We had a monitor when I first came to the school, but he was a big bully and he kept most of the food for himself...Scally was his name and he would wait in the lavatory and flog the boys who did not give him what he wanted. Scally had a strap just like the one [Brother] Walsh had'.

Tyrrell (2006) referred to another monitor who was most selfish and cruel to the younger children. Tyrrell (2006, p. 89) was of the opinion that the monitor '....often copied the Brother who was in charge of him...[and] beat the younger children under him in the same manner as he had been beaten himself (italics ours). He also referred to another monitor called Ackle, who used a heavy cane walking stick to beat boys, just as Brother Dooley did, and a monitor called Cavanagh who used a leather strap like Brother Walsh. An un-named monitor who was under Brother Walsh '....beat us in the same manner as Walsh [and] he pulled out our hair the same' (Tyrrell, 2006, p. 89; italics ours) It is not surprising that detainees took revenge upon the monitors when and if the opportunity arose:

'Just then a packed hard snowball crashed against the monitor's head...The Banner put the first kick in, followed by Stewie and Quickfart. The Sly [the monitor's nickname] was pelted with snowballs before help arrived (Touher, 2008, p. 36).

Finn (2012) reports that in the Letterfrack industrial school that physical fights between detainees were a daily occurrence and younger and smaller boys were usually attacked by bigger and older boys. As well as being physically abusive to fellow detainees, there is some evidence that monitors also perpetrated predatory sexual assaults. The Letterfrack Visitation Report of 1941 revealed that one such monitor had been '....carrying on immoral conduct with some of the juniors in the dormitory" (CICA, 2009, p. 331). In a second example, in 1945, it was learned that a monitor in charge of a large group of boys working on the farm had been beating them with a leather strap. In addition there was a suspicion of sexual abuse: Brother Maslin (a pseudonym in the CICA Report) stated that there was '....more than punishment wrong between this boy and the others" (CICA, 2009, Vol. 1, p. 298). Wall (2013, p.74) describes sexually abusive monitors in Glin who also ganged up on detainees: 
'Other predators were the monitors who beat and sexually assaulted boys; if you reported them to a Christian Brother you would then be badly beaten by the monitors'.

The CICA Report concluded that in Tralee, bullying occurred among the detainees and included physical and sexual assaults (CICA, 2009). As a result of one inspection in 1943 ,monitors were tasked with observing and guarding the toilet areas in order to prevent sexual behaviour taking place there (CICA, 2009). Again, in 1945, the Visitation Report noted widespread sexualised behaviour amongst the detainees. There is some evidence of peer sexual assault at Carriglea, as some boys who were engaged in sexual behaviour were as young as eleven years old, and the CICA Report concludes that in all probability, that they were victims of predatory behaviour (CICA, 2009). Indeed, a former detainee at Carriglea gave evidence to the CICA that as a ten year-old he had been sexually assaulted by a fellow detainee of fifteen years of age. In relation to the Artane industrial school, Brother Lionel (again, a pseudonym in the CICA Report) gave evidence to the CICA that he had punished a boy for sexually interfering with three younger boys. He said the boys had disclosed to him that 'badness' had been done to them by the other detainee (CICA, 2009, p. 138). Brother Burcet (again, a pseudonym), in his evidence to the CICA, stated that boys in Artane would be beaten on the bottom with a leather strap for interfering with other boys (CICA, 2009). A case in the Artane industrial school in the early 1960s concerned a detainee who, it seems, had sexually abused three peers, and Brother Romain (again, a pseudonym) testified that later in the decade up to a dozen boys had complained of being sexually assaulted by older boys (CICA, 2009). Flynn (1983), in writing about his own time as a detainee / pupil at the Letterfrack industrial school, recounts several examples of consensual peer sexual contact. Tyrrell (2006) reports that during his time of detention in Letterfrack, a Brother Keegan punished several boys for what were known as 'improper actions', which were said to have taken place in the dormitories and toilets, although it is unclear from Tyrell's account as to whether these 'improper actions' were consensual or not.

Clemenger (2009) recalled of his own time as a detainee / pupil at the Tralee industrial school, some senior boys had tried to sexually assault the smaller boys in the showers and toilets. Clemenger himself was the victim of peer sexual assault, including attempted rape. Wall (2013) reports having been the victim of regular sexual abuse by a particular Brother in the Glin industrial school. He says that he coped in the best way he could: 
'I did whatever he wanted me to do just to get it over and done with. While it was happening, I learned to completely disappear somewhere inside my mind' (p. 73).

Unfortunately for Wall, this Brother was not the only predator active in the industrial school. He states that as far as certain older detainees were concerned, he was now a target, and they also attempted to sexually assault him. He notes, although he doesn't say that he was a victim himself, that monitors also beat and sexually assaulted other detainees in Glin. He wanted to run away, but concluded that boys were always recaptured. He became suicidal, and contemplated jumping out the third floor of the dormitory building, because then the agony of every day would be over for him.

The CICA later heard evidence from those survivors of childhood institutional abuse who wished to report their experiences in a confidential setting. The legislation provided for the hearings of the CICA to be conducted in an atmosphere that was as informal and as sympathetic to, and understanding of, the witnesses as was possible in the circumstances. The CICA heard from 1,090 witnesses. What follows in the paragraphs bellow are examples of physical and sexual abuse that relate only to male witnesses. Thirty-eight witnesses to the Confidential Committee reported that pervasive bullying was associated with physical abuse by older boys in the schools. Witnesses reported that in some schools older boys were appointed by religious staff as monitors, and it was said that they used the opportunity to exert their authority in various ways, including beating younger boys.

'We were constantly beaten with ash wood sticks by the senior boys left in charge of the playground. This amounted to extreme cruelty as little boys, only 6 or 7 years old.... They were allowed to carry sticks and they could do what they liked' (CICA, 2009, Vol. 3, p.77).

Evidence was also heard of boys being directed by religious staff to physically assault other boys. Witnesses reported it was their belief that certain older boys were favoured by the Brothers and therefore had the freedom to behave as they wished.

'Anyway Brother [X], he urged these lads on, they started punching and kicking me, I was in ... a corner trying to hide my face from the kicks. Well I was left with blood coming from my eye, from my lip and from my eyebrow. (CICA, 2009, Vol. 3, pp. 7778). 
Physical assaults by older boys were sometimes reported to have occurred in the context of sexual abuse and witnesses reported being physically intimidated by older boys in this way as a warning against reporting the sexual abuse. There were 39 reports from witnesses of being sexually abused by other boys. Reports of sexual abuse by other boys were most often associated with physical abuse and reports of bullying.

'There was an older boy there he was the teacher's pet....He sexually abused me and most of the boys in the School. He was a right bully....[On admission] I was taken into the washroom [by] the Brother and a young fella, he was about sixteen years old. First they got me the clothes, the school clothes. They were taking me to be washed. I had to strip off in front of the young fella, the Brother went off. The young fella washed me, and then when he was drying me, he started to interfere with me, I knew what he was doing. I started to scream. The Brother came back in and said "What's happening?" [The] young fella said, "He won't let me wash him". [The Brother] gave me a slap on the face....I was only in the School for an hour' (CICA, 2009, Vol. 3, p.88).

The CICA heard nineteen witness reports of sexual abuse by older boys in a number of schools. In most instances the reports of sexual abuse were of aggressive assaults by more than one boy, and included masturbation and anal rape. Witnesses reported being accosted by older boys in the toilets, yards and corridors where there was less supervision. Seven witnesses admitted that they had sexually abused younger boys, or engaged in consensual sexual activity with another boy.

'There was things [sexual abuse] going on, between the lads, and I was absorbed into it. The way we behaved with one another, it was all based on fear. The physical violence - it was the way the whole thing was held together. You had the strongest to the weakest boys, the strongest can pick on anybody, the strongest do it to the weakest boys, and the darkness is handed out back along' (CICA, 2009, Vol. 3, p.89).

The CICA heard six reports of sexual abuse perpetrated by other boys whilst being observed by religious staff, and another nineteen reports from witnesses who believed that such behaviour was either condoned or actively encouraged by the religious staff.

'Some of the senior boys were rapists themselves....I was [sexually] abused by a lot of these older boys. Within the first three months I was there, the older boy who was on my table, he was in charge. He seemed to get on very well with the Brothers. He was always well treated by the Brothers. He abused me in a garden shed with 
another boy and a Brother. They subjected me to being raped, and I was threatened that I would be thrown in the slurry pit. The Brother [anonymised in the original report] raped me in front of the boy. That was the only time where there was a boy and a Brother together. (CICA, 2009, Vol.3, p. 89).

\section{Peer Abuse and Repetition Compulsion}

As well as those incidences where peer abuse was either condoned or encouraged by the adults in the industrial schools, having reviewed the evidence, it seems reasonable to suggest that at least some of the peer physical abuse, peer bullying and peer sexual abuse observed in industrial schools in Ireland may have reflected the operation of a defence mechanism - what might be readily referred to these days as a pattern of re-enactment, or 'acting out'. That is to say, we believe the evidence that exists supports the hypothesis that many of these peer abuse patterns were the direct consequences of detainees' own experiences of being abused by adults in the industrial school. The Freudian defence mechanism of repetition compulsion was originally formulated in his 1920 essay 'Beyond the Pleasure Principle'. In applying this concept to the industrial school situation, we might say that the detained boys identified with their adult abusers, and then compulsively repeated or acted out the physical and sexual abuse that they had experienced. It is noteworthy that the invitations to identify with adult abusers were certainly made towards those boys who were empowered as 'monitors'. It is noteworthy that survivor accounts from Auschwitz (see Frankl, 1959; Levi, 1979) document that Kapos, those prisoners who were given leadership roles amongst their fellows by the concentration camp authorities, enjoyed certain special privileges in the camp, and were often far more cruel in their punishments than were the SS soldiers. Both Frankl (1959) and Levi (1979) were quick to point out the trivial nature of some of these Kapos' positions of authority; (Levi (1979) referred to a supervisor of the latrines, who revelled in the power that his role as Scheissminister (a term that perhaps needs no translation) provided. Nevertheless, Kapos had very significant power (including, by both direct and indirect means, the power of life and death) over their fellow prisoners.

In clinical settings, such patterns of re-enactment or repetition compulsion were later observed and described by therapists working with victims of abuse as a spontaneous attempt to integrate the traumatic event. It was, therefore, seen as an understandable (whilst of course, problematic) coping mechanism (e.g., Herman, 1992a, 1992b). Children seem to be particularly vulnerable to compulsive behavioural repetition, and in so doing may play the role of either victim, or victimiser (van der Kolk, 1989). This repetitive acting out of the traumatic event is what we sometimes observe in the sexualised behaviour of victims of abuse. A number of studies have reported that the presence of sexual behaviour problems in 
child victims, for example, appears to be one of the most common after effects of sexual abuse. In a review across thirteen studies regarding children's sexual behaviour, of 1,353 sexually abused children, 28 per cent exhibited highly sexualised behaviour (Kendall-Tackett, Williams, \& Finkelhor, 1993).

\section{Conclusions}

In the early part of this paper, we considered the systemic factors that were operational in the development of the industrial schools system in Ireland. We saw how the very systems (social, religious and legal) that had rendered the young people detained in industrial schools so absolutely powerless and voiceless (indeed, that had positioned them as the 'moral dirt of society', and justified and facilitated their treatment as such under the guise of reform) also supported (i) their being subject to physical and sexual abuse from adults and child / teenaged peers alike; and, (ii) the concealing of these facts for years. For over a century, many vulnerable people, especially children, lived a parallel and precarious existence in an Irish society that '....claimed to cherish and hold them sacred, but in fact marginalised and ignored them' (Maguire, 2012).

We feel that as a society, we owe it to ourselves, and to those can no longer testify to their experiences, to engage with these contradictions and these horrific truths of the past. Part of this engagement is to make every effort to position the peer abuse that took place in industrial schools in its correct contexts; with such behaviours having been of such a serious and criminal nature, and apparently so prevalent, that a failure to contextualise these behaviours can only seem to support the idea that the detainees really were the 'moral dirt' that they had been positioned as. We owe the survivors of the industrial schools far, far more than another act of what has been, for many, a life-long series of disparagements, and we would hope that this paper can be a small gesture in this direction.

\section{References}

Arnold, B. (2009). The Irish Gulag: How the State Betrayed its Innocent Children. Dublin: Gill \& Macmillan.

Arnold, M. \& Laskey, H. (1985). Children of the Poor Clares: The Story of an Irish Orphanage. Belfast: Appletree Press.

Barnes, J. (1989). Irish Industrial Schools 1868-1908: Origins and Development. Dublin: Irish Academic Press. 
Banbury, S. (2004). Coercive sexual behaviour in British prisons as reported by adult ex-prisoners. Howard Journal of Criminal Iustice, 43(2): 113-130.

DOI: $10.1111 / \mathrm{j} .1468-2311.2004 .00316 . x$

Beck, A.J.; Berzofsky, M. Caspar, R. \& Krebs, C. (2013). Sexual victimization in prisons and jails reported by inmates, 2011-12: National Inmate Survey, 2011-12. United States Department of Justice: Bureau of Justics Statistics. Available directly on the world-wide web: http://www.bjs.gov/content/pub/pdf/svpjri1112.pdf

Buckley, S. (2013). The Crueltv Man: Child Welfare the NSPCC and the State in

Ireland, 1889-1956. Manchester University Press.

Carpenter, M. (1851/2013). Reformatory Schools for the Children of the Perishing and Dangerous Classes, and for Juvenile Offenders. Cambridge University Press.

Chapman, A. \& O' Donoghue, T. (2007). The recruitment of religious as teachers: A case study from 1960s Australia. Cambridae Iournalof Education, 37 (4), 561-577.

Clemenger, M. (2009). Holy Terrors. Dublin: O’ Brien Press.

Clemmer, D. (1940). The Prison Community. Boston, MA: The Christopher Publishing.

Coldrey, B. (2001). 'The extreme end of a spectrum of violence': Physical abuse, hegemony and resistance in British residential care. Children \& Societv, 15, 95-106.

Commission to Inquire into Child Abuse Vols. 1-5 (2009). Report of the Commission to Inquire into Child Abuse Vols. 1-5. Dublin: Stationery Office.

Cussen, G.P. (1936). Commission of Inquiry into the Reformatory and Industrial School System, 1934-1936. Dublin: Stationery Office.

Edgar, K.; O' Donnell, I. \& Martin, C. (2003). Prison Violence: The Dynamics of Conflict, Fear and Power. Cullompton, Devon: Willan Publishing.

Fergusen, H. (2007). Abused and looked after children as 'moral dirt': child abuse and institutional care in historical perspective. Lournalof SocialPolicy, 36 (1), 123139.

Finn, M. (2012). In My Own Words (Still Running). Self-published (lulu.com). 
Flynn, M. (1983). Nothing to Say. Dublin: Ward River Press.

Frankl, V.E. (1959 / 1985). Man's Search for Meaning. New York: Washington Square Press.

Freud, S. (1920). Beyond the pleasure principle. In the Penguin Freud Library, vol. 11 (ed. and transl. J. Strachey). Harmondsworth: Penguin Books.

Garabedian, 1964. Social roles and processes of socialization in the prison community. Social Problems, 11: 137-152.

Goffman, E. (1961 / 1975). Asylums: Essays on the social situation of mental patients and other inmates. Harmondsworth: Pelican Books.

Herman, J.L. (1992a). Complex PTSD: A syndrome in survivors of prolonged and repeated trauma. Lournal of Traumatic Stress, 5(3): 377-391.

DOI: $10.1002 /$ jts.2490050305

Herman, J.L. (1992b). Trauma and Recovery: The Aftermath of Violence: From Domestic Abuse to Political Terror. New York: Basic Books.

The Howard League for Penal Reform (2014). Suicides in Prison. Available directly on the world-wide web: http://www.howardleague.org/suicidesinprison/

Kendall-Tackett, K.A.; Williams, L.M. \& Finkelhor, D. (1993) Impact of sexual abuse on children: A review and synthesis of recent empirical studies. Psvchological Bulletin, Vol 113(1): 164-180. DOI: http://dx.doi.org/10.1037/00332909.113.1.164

Kennedy, E. (1970). Reformatory and Industrial Schools Systems Report. Dublin: Stationery Office.

Levi, P. (1979 / 2006). If This is a Man and The Truce. London: Abacus.

Lynch, D. and Burns, K (Ed.). (2012) Children's Rights and Child Protection: Critical Times, Critical Issues in Ireland. Manchester University Press.

MacLellan, A. \& Mauger, A. (Eds.) (2013). Growing Pains: Childhood Illness in Ireland 1750-1950. Dublin: Irish Academic Press. 
Maguire, M.J. (2012). Precarious Childhood in Post-Independence Ireland. Manchester: Manchester University Press.

O'Sullivan, D. (1976). An Irish industrial school viewed as a socializing agent with particular reference to its social organization. Unpublished PhD thesis, NUI Galway.

O'Sullivan, D. (1978). Negotiation in the maintenance of social control: A study in an Irish correctional school. International Journal of Criminology and Penology, 6, 3142.

O'Sullivan, E. and O'Donnell, I. (2007). Coercive confinement in the Republic of Ireland: the waning of a culture of control. Punishment and Societv 9(1), 27-48.

Raftery, M \& O'Sullivan, E. (1999). Suffer the Little Children: The Inside Story of Ireland's Industrial Schools. Dublin: New Island.

Ricciardelli, R. (2014). Investigating how male prisoners manage the threat of victimization in federal prisons. The Prison Journal, 94(4): 411-434. doi:

$10.1177 / 0032885514548001$

Stohr, M.K. \& Walsh, A, (2015). Corrections: The Essentials. London: Sage.

Sykes, G.M. (1958). The Society of Captives: A Study of a Maximum Security Prison. Princeton, NJ: Princeton University Press.

Sykes, G.M \& Messinger, S. (1960). The inmate social system. In R. A. Cloward, D. R. Cressey, G. H. Grosser, R. McCleery, L. E. Ohlin, G. M. Sykes \& S.L. Messinger (eds.), Theoretical Studies in Social Organization of the Prison (pp. 5-19). New York: Social Science Research Council.

Touher, P. (2001). Fear of the Collar: My Terrifying Childhood in Artane. Dublin: O' Brien Press.

Touher, P. (2008). Scars that Run Deep: Sometimes the Nightmares Don't End. Dublin: O’ Brien Press.

Tuairim (1966). Some of our Children: A Report on the Residential Care of the Deprived Child in Ireland. Dublin: Irish Printers. 
Tyrrell (2006). Founded on Fear: Letterfrack Industrial School, War and Exile. Dublin: Irish Academic Press.

Van der Kolk, B.A. (1989). The compulsion to repeat the trauma: Re-enactment, revictimization, and masochism Psychiatric Clinics of North America, 12 (2): 389411.

Wall, T. (2013). The Boy from Glin Industrial School. Self-published. 